University of Wollongong

Research Online

Faculty of Business - Papers (Archive)

Faculty of Business and Law

$1-1-2017$

Modelling quality dynamics, business value and firm performance in a big data analytics environment

Steven Ji-Fan Ren

Shenzhen University

Samuel Fosso Wamba

Toulouse Business School, samuel.fosso.wamba@neoma-bs.fr

Shahriar Akter

University of Wollongong, sakter@uow.edu.au

Rameshwar Dubey

Constituent Of Symbiosis International University

Stephen J. Childe

Plymouth Business School

Follow this and additional works at: https://ro.uow.edu.au/buspapers

Part of the Business Commons

Research Online is the open access institutional repository for the University of Wollongong. For further information contact the UOW Library: research-pubs@uow.edu.au 


\title{
Modelling quality dynamics, business value and firm performance in a big data analytics environment
}

\author{
Abstract \\ Big data analytics have become an increasingly important component for firms across advanced \\ economies. This paper examines the quality dynamics in big data environment that are linked with \\ enhancing business value and firm performance (FPER). The study identifies that system quality (i.e. \\ system reliability, accessibility, adaptability, integration, response time and privacy) and information \\ quality (i.e. completeness, accuracy, format and currency) are key to enhance business value and FPER in \\ a big data environment. The study also proposes that the relationship between quality and FPER is \\ mediated by business value of big data. Drawing on the resource-based theory and the information \\ systems success literature, this study extends knowledge in this domain by linking system quality, \\ information quality, business value and FPER.

\section{Disciplines} \\ Business

\section{Publication Details} \\ Ren, S. Ji-Fan., Fosso Wamba, S., Akter, S., Dubey, R. \& Childe, S. J. (2017). Modelling quality dynamics, \\ business value and firm performance in a big data analytics environment. International Journal of \\ Production Research, 55 (17), 1-16.
}


MODELLING QUALITY DYNAMICS ON BUSINESS VALUE AND FIRM PERFORMANCE IN BIG DATA ANALYTICS ENVIRONMENT 


\begin{abstract}
Big data analytics have become an increasingly important component for firms across advanced economies. This paper examines the quality dynamics in big data environment that are linked with enhancing business value and firm performance. The study identifies that system quality (i.e., system reliability, accessibility, adaptability, integration, response time and privacy) and information quality (i.e., completeness, accuracy, format and currency) are key to enhance business value and firm performance in big data environment. The study also proposes that the relationship between quality and firm performance is mediated by business value of big data. Drawing on the resource based theory and the information systems success literature, this study extends knowledge in this domain by linking system quality, information quality, business value and firm performance.
\end{abstract}

Keywords: Big Data Analytics, Business Values, Information Quality, System Quality, Firm Performance. 


\section{INTRODUCTION}

Studies on the business value from information systems (IS) investments have reported mixed results. Some scholars argue that IS investments are not always translated into improved operational efficiency and effectiveness, and thus leading to the so called "IT productive paradox" (Roach et al., 1987; Solow, 1987; Strassmann, 1990). Another set of scholars did actually identify a positive relationship between IS investments and firm performance (Barua et al., 2004; Barua et al., 1995a; Brynjolfsson and Yang, 1996). This study argues that the absence of relationship between IS investment and firm performance reported in early studies was mainly due to a set of reasons including the unavailability of appropriate data, the existence of a time lags between IS investment and business value generated from these investments, the lack of the assessment of the indirect benefits of IT, and the level of analysis of IS-related benefits (Brynjolfsson and Hitt, 2000; Brynjolfsson and Yang, 1996; Devaraj and Kohli, 2003). In fact, scholars within this stream of research argue that the impact of IT on firm performance may be mediated by a number of intermediate variables (Anand et al., 2013; Mooney et al., 1996). Furthermore, they propose to have a more broad view of IT resources by integrating its multidimensional perspectives into any given study on business value of IT (Bharadwaj, 2000; Bhatt and Grover, 2005; Santhanam and Hartono, 2003). In this paper, we extend this stream of research by looking at factors contributing to the improved firm performance from IS enabled big data analytics (BDA) investments. BDA is defined as "a collection of data and technology that accesses, integrates, and reports all available data by filtering, correlating, and reporting insights not attainable with past data technologies" (APICS, 2012). Recently, BDA has emerged as a new information technology (IT) frontier to transform the way firms do business. It is emerging as the "next big thing" in management. Some scholars even propose that BDA is the "next management revolution"(McAfee and Brynjolfsson, 2012c), and thus generating huge attention from both practitioners and academics because of its high operational and strategic potentials in transforming businesses (Trkman et al., 2012). Moreover, the incessant growth 
in worldwide IS expenditure on BDA continues to motivate studies on business value generated from these investments. According to (Columbus, 2014a), "87\% of enterprises believe Big Data analytics will redefine the competitive landscape of their industries within the next three years. $89 \%$ believe that companies that do not adopt a Big Data analytics strategy in the next year risk losing market share and momentum". However, the assessment of the real value of IS investments in BDA still represents a challenging and controversial mission in terms of systems and information quality and their impact on business value and firm performance (Agarwal and Dhar, 2014; Goes, 2014; Lavalle et al., 2011; McAfee and Brynjolfsson, 2012c; Verbraken et al., 2012). Yet, very few empirical studies have been conducted to assess the real business value of BDA at the firm and production levels. Therefore, the study aims at examining the following research question:

What are the impacts of systems quality and information quality on both business value and firm performance?

We address this question by consulting the literature on the resource based theory (RBT), IS success and implementation. We propose a research model to explore the impact of BDA on firm performance, modelling the impact of system quality, information quality, and business value. In particular, we propose to study the direct and indirect effects of BDA information quality and BDA system quality on firm performance. In developing our theoretical model, we argue that BDA system quality and BDA information quality will have a positive impact on business value from BDA, which in turn will influence the firm performance.

By presenting the research model on quality dynamics, business value and firm performance in big data environment, the study contributes to BDA research in several ways. First, the research extends the literature in big data exploring the relationship between system and information quality, business value and firm performance. Prior research has largely focused on anecdotal evidences in highlighting the importance of quality dynamics on outcome constructs (Barton and Court, 2012a; Davenport et al., 2012a). Second, the research specifically examines the mediating role of business 
value in modelling the indirect impact of quality on firm performance. The findings of the study suggest that the effectiveness of system and information quality in influencing firm performance is contingent on the extent of business value. Third, the study explores sub dimensions that are specific to the system and information quality of BDA platform, which provides solutions to the emerging challenges of analytics platform. Overall, the uniqueness of the conceptual model lies in assessing quality dynamics of an innovative IT artefact (i.e., BDA) on business value and performance. The organization of this paper is as follows: the next section focuses on the theoretical foundations and research hypotheses. This is followed by the research method and data analysis. The discussion section is followed. The last section focuses on the study's conclusion, theoretical and practical contributions and provides guidelines for future research.

\section{THEORETICAL FOUNDATIONS AND RESEARCH HYPOTHESES}

Drawing on the literature on resource-based theory (RBT), IS success and business value of IT, this study puts forward the research model in Figure 1. In this model, we argue that the quality of system and information in BDA environment have significant impact on business value, which in turn will influence the firm performance.

The RBT focuses on the relationship between resources/capabilities and firm performance (DeSarbo, W. S., Di Benedetto, C. A., \& Song, M. 2007). A central theme of RBT is that the firm performance depends on the attributes/qualities of that firm's resources and capabilities (Barney, 2014). The qualities indicate that resources must be valuable, rare, inimitable and non-substitutable. According to Kaufman (2015), "the value component V creates the extra potential profit, and the rare, inimitable and non-substitutable components RIN allow firms to capture the extra value". Focusing on the qualities of resources, Barney (1991) puts forward two critical questions: first, what qualities of resources make some firms more successful than others and second how can firms enhance sustainable performance? These two questions highlight the theoretical underpinning of this study, which clearly illuminate the relationship between the excellence (or, qualities) of resources and firm 
performance. The RBT suggests that the potential of high performance is greater when various quality resources are developed inside the firm to generate firm specific value using in-house investments, resource complementarities and complex systems (Kaufman, 2015). From the RBT perspective, system and information quality are broadly identified as the distinctive attributes of the BDA to support productivity in terms of logistics and inventory management, setting the optimal price and managing demand and supply (Davenport and Harris, 2007). The competency of BDA is driven by system and information qualities to achieve firm performance (FPER) (Grant, 2002). Indeed, the RBT highlights the critical roles of such attributes to achieve competitive advantages (Amit and Schoemaker, 1993; Barney et al., 2001). According to Barney (2014, p.24), "A central tenet of resource-based theory is that the return potential of a firm's strategies depends on the attributes of that firm's resources and capabilities".

In IS success theory (DeLone and McLean, 1992), both system and information quality have been identified as important factors of IT driven value and performance. Teo and Wong (1998) in their empirical study on the performance impact of computerization in the retail industry found that information quality is positively related to improvement in work environment (an intermediary impact), as well as organizational impact. Similarly, Gorla et al. (2010) identified a positive relationship between information quality and organizational impact. In fact, Gorla et al. (2010) argued that information quality will mediate the relationship between system quality and organizational impact. While they found a positive relationship between system quality and information quality respectively, and information quality and organizational impact, the direct effect between system quality and organizational impact was not significant. Ram et al. (2014) found that system quality is an important antecedent of ERP implementation success that needs to be managed appropriately in order to achieve competitive advantage with ERP projects. Prior studies reported a strong positive relationship between information quality - business value - firm performance (DeLone and McLean, 2003, 2004; Ram et al., 2014) as well as between system quality and firm 
performance in terms of improved problem solving, autonomy in job performance, management visibility and cross functionality (Ram et al., 2014).

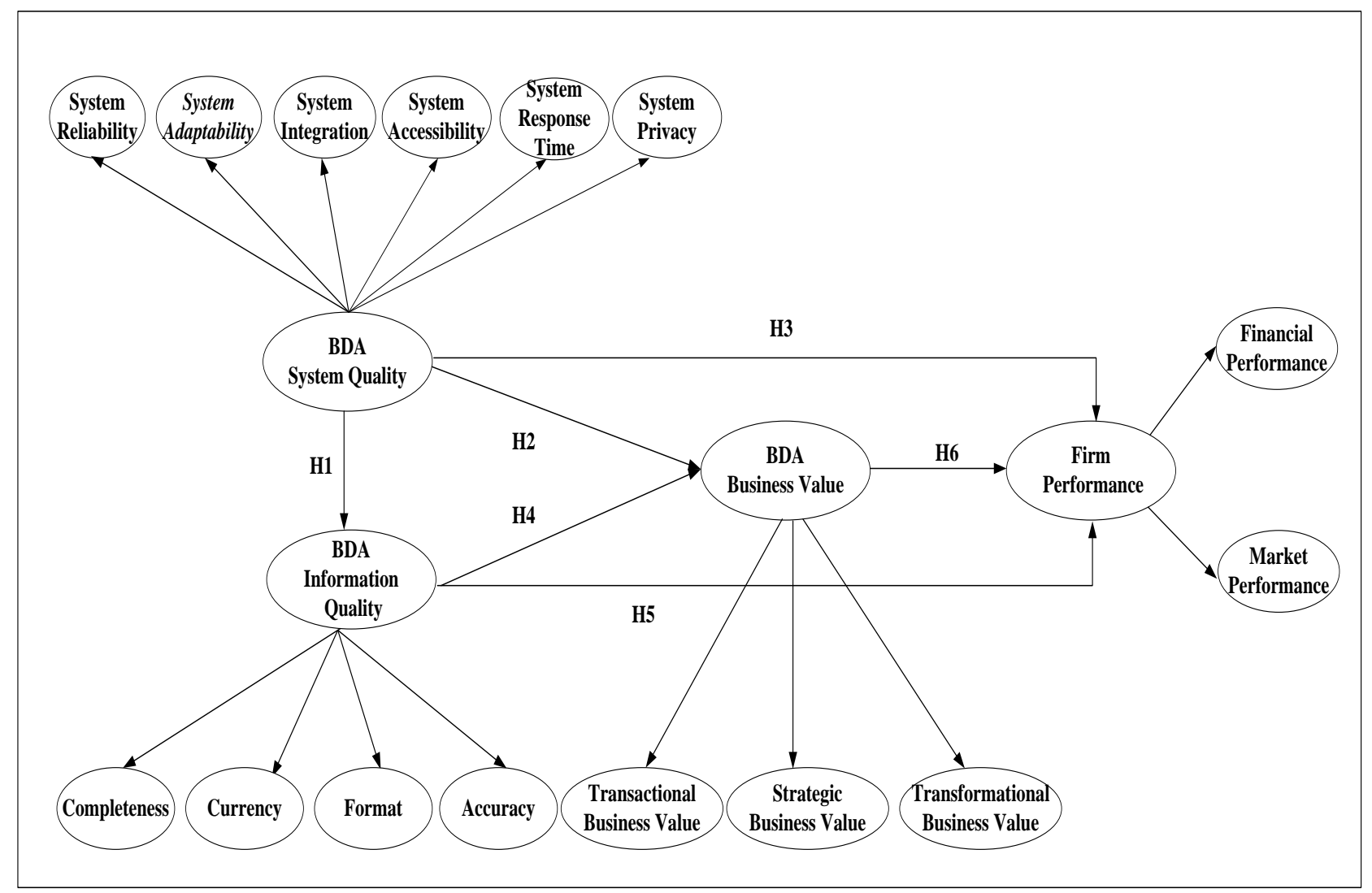

Figure 1.Research model

\subsection{System quality and Information quality}

The RBT of the big data analytics posits that organizational outcomes depend on the quality of resources that are unique in the marketplace. It takes into account heterogeneous resources and their connections, such as system and information quality, to examine competitive advantages. Illuminating the importance of heterogeneous resources and their relationships in big data environment, Barton and Court (2012a,p.80) states that "The promised gains in performance were often slow in coming, because the systems remained stubbornly disconnected from how companies and frontline managers actually made decisions, and new demands for data management added complexity to operations". They argue that the quality of technology determine the extent of 
information quality in big data environment. Indeed, the objective of BDA is to develop an information ecosystem that helps in sharing information, optimizing decisions, communicating results and generating new insights for businesses (Davenport et al., 2012b). As more firms apply big data, building superior systems quality may soon become decisive competitive asset to enhance information quality (Fosso Wamba et al., 2015). Since quality information is a foundation of good decision making and positive outcomes, yet we know little about the impact of system quality on information Quality. Thus, we posit that:

H1: BDA system quality has a significant positive effect on BDA information quality.

The RBT viewpoint suggests that an IT resource cannot explain variance in the performance of a system if it is not rare and not costly to imitate (Ray et al., 2005). We define system quality of a BDA firm as an IT resource that is valuable and rare, such as movie recommendations systems of Netflix or dynamic pricing of Amazon. System quality basically represents the technical aspects of an analytics platform, which are firm specific, developed over time and difficult to imitate. The review of the BDA literature identifies five sets of qualities: system reliability, system adaptability, system integration, system accessibility, system response time and system privacy in providing solid insights (Davenport et al., 2012a; Davenport and Harris, 2007; Fosso Wamba et al., 2015; McAfee and Brynjolfsson, 2012b). These quality dimensions are specified in the model as the primary components of system quality to predict business value (BVAL) and firm performance (FPER). First, system reliability indicates the dependability of an analytics platform that managers can rely on a platform which is free from any disruption or interference (Nelson et al., 2005). Second, system adaptability refers to the extent to which analytics platform can be adapted to meet various needs in changing situations (Kiron et al., 2014; Nelson et al., 2005). Third, system integration refers to the ability of the analytics platform to integrate variety of data (i.e., transaction, clickstream, voice and video)(Davenport et al., 2012a; Kiron et al., 2014). Fourth, system accessibility measures the extent 
to which an analytics platform is accessible to managers, ensuring convenience and scalability (Davenport et al., 2012a). Fifth, system response time measures timeliness and promptness of the analytics platform(McAfee and Brynjolfsson, 2012b). Finally, system privacy refers to the extent to which the analytics platform is safe and there is no possibility of leaking private information (Barton and Court, 2012a). Since system quality lies at the heart of BDA, characteristics of the underlying system play a critical role in creating business values (Gregor et al., 2006; Melville et al., 2004). We propose that the quality of a system in a BDA environment will affect the relationships between business value (BVAL) and firm performance (FPER). McAfee and Brynjolfsson (2012a) identify system quality as a necessary component of a big data strategy in order to handle the volume, velocity and variety of data. Indeed, the qualities of information in big data environment depend on a large extent on the qualities of a system, which ensure BVAL and better FPER. Thus, we posit that:

H2: BDA system quality has a significant positive effect on BDA business value.

H3: BDA system quality has a significant positive effect on firm performance.

Using the RBT viewpoint, we also define information quality as a BDA resource because valuable and rare information establish competitive advantages in big data environment (Davenport, 2006; Schläfke et al., 2013). In addition, information resources are imperfectly imitable due to its unique processing, causal ambiguity or social complexity (Barney and Clark, 2007). Thus, the ultimate challenge in BDA is to find pattern in data and translate them into useful information (Davenport et al., 2012a). We define information quality as the completeness, accuracy, format, and currency of information produced by BDA. Completeness indicates the extent to which the user perceives that BDA provide all the necessary information; accuracy focuses on the perceived correctness of information; format refers to the perception of how well the information is presented; and, finally, currency refers to the user's perception of the extent to which the information is up to date (Wixom and Todd, 2005). For instance, BDA used in financial organizations combine data across various platforms (e.g., ATMs, online banking, face to face banking) in order to provide more complete 
information (Barton and Court, 2012b). In addition, it is also critical to ensure accuracy of information as BDA deals with "dirty data" from multiple sources, which needs to be organized and processed. Information quality also focuses on formatting insights which could be done through filtering and better visualization of results (Wixom et al., 2013). Finally, currency of information should also receive attention because continuous flow and sharing of information help managers make real-time decisions (Davenport et al., 2012a). In the financial industry, real time information can play a huge role in detecting fraud and tracking customer transactions (Davenport, 2006). Overall, we propose that information quality is a resource in big data environment that enables the organization to enhance business value and firm performance (Fosso Wamba et al., 2015; Kiron et al., 2014; Wixom et al., 2013). According to the RBT, the asymmetric nature of information in data economy may help analytics firm build competitive advantage in terms of business value and firm performance. Indeed, increased level real time information across the organizational units is linked with increased organizational performance. According to Mithas et al. (2013, p.18), "[t]he goal of big data programs should be to provide enough value to justify their continuation while exploring new capabilities and insights". Thus, we posit that:

H4: BDA information quality has a significant positive effect on BDA business value.

H5: BDA information quality has a significant positive effect on firm performance.

\subsection{Business Value and Firm Performance}

The RBT views that a firm can exploit full competitive potential of its resources and capabilities when they are valuable, rare and imperfectly imitable (Barney and Hesterly, 2012). The interest toward assessing the business value and firm performance from technology resources in BDA gains an increasing attention (Kiron et al., 2014; McAfee and Brynjolfsson, 2012b). After resources and capabilities, the RBT identifies business value and firm performance as its central constructs (Kozlenkova et al., 2014). Researchers suggest that resource complementarity, such as the benefits of 
strong system quality is leveraged by information quality, contributes to better business value and firm performance (Morgan et al., 2009). Interest in RBT in big data environment stems from its potential influence on business value and firm performance. A firm is said to have competitive advantage from BDA when it enjoys greater success than its competitors (Davenport, 2006; Peteraf and Barney, 2003). Aligned with this conceptualization of RBT, we propose that superior business value and firm performance serves as empirical indicators of competitive advantage in big data environment. Thus, it is important to conceptualize the differences between business value and firm performance and distinguish them from resources (i.e, system quality and information quality) to understand the nomological net.

Many conceptualizations of business values from technology resources have been proposed by scholars. For example, Zuboff (1988) identified three categories of IT business value: informational, automational and transformational. Gregor et al. (2006) conceptualized IT business value in terms of informational, strategic and transactional benefits. Some scholars argue that technology resources are important enablers and drivers of business value in terms of business process efficiency and effectiveness, which in turn influence overall firm performance (Chang and King, 2005; Jayachandran et al., 2005). Prior studies (Barua et al., 1995b; Grant, 1991; Mooney et al., 1996) found that the technology resources contribute to business value and influence the overall firm performance. Overall, we define business value of BDA as the transactional, informational and strategic benefits for the BDA firms. Whereas transactional value focuses on improving efficiency and cutting costs, informational value sheds light on real time decision making and strategic value deals with gaining competitive advantages.

The extant literature on BDA frequently illuminates the link between business value and firm performance. For example, Wixom et al. (2013) proposed that BDA driven business value can influence both tangible (i.e., cutting down paper based reporting) and intangible (brand image) firm performance. Similarly, Srinivasan and Arunasalam (2013) argued that predictive analytics based 
BDA and text mining transformed healthcare industry by cutting cost (i.e., waste and fraud reduction) and ensuring better quality of care (i.e., efficiency and security in treatment). Furthermore, A recent study by Court (2015) shows that BDA could increase operating margins by $60 \%$ if there is a right alignment between quality, value and performance. For example, organizations with BDA can increase new products and services creation (70\%), expand into new markets (72\%), satisfy customer needs at the right time and place (79\%) and improve sales and revenue (76\%) with the help of robust system and information quality (Columbus, 2014b). Thus the study hypothesizes that:

H6: BDA business value has a significant positive effect on firm performance.

\section{RESEARCH METHOD}

\subsection{Scale Development and Sampling}

The questionnaire consists of previously published multi-item scales with favourable psychometric properties (see Table 1). All the constructs in the model were measured using 7-point Likert scale (e.g. strongly disagree-strongly agree). A cross-sectional survey was used to collect the data and test the research model. The data collection consists of three steps. Before the main survey, a pilot study was conducted to ensure the reliability and validity of the measures. The questionnaires were distributed to 42 selected business analysts in engineering master programs of Chinese university, and the measures ensured good reliability and validity. The final items used in the questionnaire and their sources are listed in Table 1. 
Table 1. Constructs and definitions

\begin{tabular}{l|l|}
\hline Construct and definition & Sources \\
\hline BDA System quality is defined as systems reliability, system & \\
adaptability, system integration, system accessibility, system \\
response time, and system privacy. System reliability refers to the \\
degree to which the BDA system is reliable over time; System \\
adaptability refers to degree to which the BDA system can adapt to \\
a variety of user needs and Changing conditions; system integration \\
refers to the ability to integrate various sources of data to produce \\
meaningful insights; system accessibility refers to the extent to \\
which the BDA system is available over time, system response time \\
refers to the promptness of a system to respond to the client's \\
needs; and finally, System privacy refers to the degree to which the \\
BDA system is safe and protects user information. \\
\hline $\begin{array}{l}\text { BDA Information quality is defined as the completeness, accuracy, } \\
\text { format, and currency of information produced by BDA. } \\
\text { Completeness indicates the extent to which the user perceives that } \\
\text { BDA provide all the necessary information; accuracy focuses on } \\
\text { the perceived correctness of information; format refers to the } \\
\text { perception of how well the information is presented; and, finally, } \\
\text { currency refers to the user's perception of the extent to which the } \\
\text { information is up to date. }\end{array}$ \\
\hline $\begin{array}{l}\text { BDA Business value is defined as the transactional, strategic, and } \\
\text { transformational value of BDA. Transactional value refers to the } \\
\text { degree to which the user perceives that BDA provide operational } \\
\text { benefits, e.g., cost reductions: strategic value refers to the degree of } \\
\text { perceived benefits to the organization at a strategic level, e.g., } \\
\text { competitive advantage; and, finally, transformational value refers to } \\
\text { the degree of perceived changes in the structure and capacity of a } \\
\text { firm as a result of BDA, which serve as a catalyst for future } \\
\text { benefits. }\end{array}$
\end{tabular}

As the study is the on the firm level, we followed previous study and surveyed IT managers. The main survey was conducted by a market research firm having a database of more than 10000 listed Chinese IT managers and business analysts. An online questionnaire was distributed to 500 samples using simple random sampling. In around two weeks, we received responses from 315 samples. We have set a screening question: has your company previously invested in big data and business analytics solutions? We excluded those responses from the study which answer is no. We also deleted the responses having incomplete answers. The usable questionnaires were 225 . In order to establish adequate statistical power in our findings, we further asked the market research firm to 
distribute the survey to another 200 people, and 90 more responses were received, among them 62 are usable. The final usable questionnaires were 287 . Overall, the response rate was $63 \%(315 / 500)$ in the first round and $45 \%(90 / 200)$ in the second round. $78 \%$ of the respondents are male, and the majority of them (more than 66\%) have an undergraduate degree or above. $83 \%$ of them are IT managers, other are top managers that in charge of IT sectors. Table 2 represents the demography of the respondents and characteristics of their firms, such as industries.

\section{DATA ANALYSIS}

In order to estimate the second-order hierarchical system quality, information quality, business value and firm performance, the study applied PLS-SEM because it estimates hierarchical model by removing the uncertainty of inadmissible solutions using its flexible assumptions (Hair et al., 2011; Hulland et al., 2010). PLS path modeling allows for estimating the hierarchical model in order to achieve more theoretical parsimony and less model complexity (Edwards, 2001; Wetzels et al., 2009). For instance, using PLS path modeling, Wetzels et al. (2009) developed a fourth-order hierarchical-reflective model in online experiential value to predict e-loyalty. Akter et al (2010; 2013) developed a third-order service quality model and a second-order trustworthiness model for service systems. Hierarchical modeling can be done in two different ways based on the relationship between latent variables and manifest variables, that is, hierarchical-reflective modeling and hierarchical-formative modeling. In the reflective model, the latent variables reflect the manifest variables ( $L V s \rightarrow M V s$ ) whereas in the formative one, the manifest variables form the latent variables $(M V s \rightarrow L V s)$. The reflective construct is generally viewed as giving rise to its indicators (Fornell \& Bookstein 1982) but the formative construct views its indicators as defining characteristics (Rossiter 2002). Thus, the proposed BDA model as a hierarchical-reflective model. 
Table 2. Demographic profile of respondents

\begin{tabular}{|c|c|c|}
\hline Dimension & Category & $\begin{array}{c}\text { Percentage } \\
(\%)\end{array}$ \\
\hline \multirow{5}{*}{ Education } & Primary qualification & 2.44 \\
\hline & Secondary qualification & 6.97 \\
\hline & College qualification (diploma/certificate) & 15.68 \\
\hline & Undergraduate degree & 64.46 \\
\hline & Postgraduate degree (Master/Ph.D.) & 10.45 \\
\hline \multirow{5}{*}{ Age } & $18-25$ years old & 21.95 \\
\hline & 26-33 years old & 43.90 \\
\hline & $34-41$ years old & 30.66 \\
\hline & $42-49$ years old & 3.14 \\
\hline & 50 years old or older & 0.35 \\
\hline \multirow{2}{*}{ Gender } & Male & 78.80 \\
\hline & Female & 21.20 \\
\hline \multirow{19}{*}{ Industry } & Accommodation and food service activities & 5.23 \\
\hline & Administrative and support service activities & 6.27 \\
\hline & Agriculture, forestry and fishing & 1.39 \\
\hline & Arts, entertainment and recreation & 1.74 \\
\hline & Construction & 4.88 \\
\hline & Education & 2.44 \\
\hline & Electricity, gas, steam and air conditioning supply & 1.05 \\
\hline & Financial and insurance activities & 12.54 \\
\hline & Human health and social work activities & 0.00 \\
\hline & Information and communication & 36.24 \\
\hline & Manufacturing & 14.63 \\
\hline & Mining and quarrying & 0.70 \\
\hline & Professional, scientific and technical activities & 3.14 \\
\hline & Public administration and defense; compulsory social security & 0.00 \\
\hline & Real estate activities & 1.74 \\
\hline & Transportation and storage & 2.44 \\
\hline & Water supply; sewerage, waste management & 0.00 \\
\hline & Wholesale and retail trade; repair of motor vehicles & 2.09 \\
\hline & Other service activities & 3.48 \\
\hline
\end{tabular}

\subsection{Measurement Model}

In order to assess the hierarchical research model, this study uses PLS Graph 3.0 (Chin, 2001) to estimate the parameters in the outer and inner model. In this case, the study applies PLS-SEM with a path weighting scheme for the inside approximation. Then the study applies nonparametric bootstrapping (Chin, 2010; Efron and Tibshirani, 1993) with 5000 replications to obtain the standard errors of the estimates (Hair et al., 2013).

The measurement model was evaluated prior to the structural model in order to assess construct reliability, unidimensionality, convergent validity, and discriminant validity. The model includes six 
constructs with 20 items. In Table 3, descriptive statistics of the constructs are presented. Internal consistency, convergent validity, and discriminant validity were further evaluated by examining the Cronbach's alpha, composite reliability, and average variance extracted (AVE) of each construct. Table 4 shows the standardized loadings and reliabilities of the latent constructs in the model. All the item loadings were greater than the criterion 0.80 (Fornell and Larcker, 1981b) and significant $(p<0.01)$. The values of Cronbach's alpha and composite reliabilities were all greater than 0.707 (Nunnally and Bernstein, 1994). In addition, the AVE for each construct was higher than 0.50, suggesting that observed items explain more variance than the error terms (Fornell and Larcker, 1981a). Unidimensionality was also supported by AVEs (>0.50) and composite reliabilities $(>0.70)$ (Segers, 1997). As shown in Table 5, the square root of AVE of a construct was higher than its correlations with other constructs, suggesting good discriminant validity of the measurement model in this study.

We also tested whether the principal factor counting for the majority of the variance explained in order to identify potential common method bias (Podsakoff and Organ, 1986). The Harman's one factor test generates 6 factors and the first factor accounts for only 20 percent of total variance, which indicates that the common method of bias would not be a big problem. Furthermore, the correlation matrix (Table 5) shows that the highest inter-construct correlation is 0.54 , while common method bias is usually evidenced by extremely high correlations ( $\mathrm{r}>0.90)$ (Bagozzi et al., 1991). Therefore, the common method bias in this research is not serious issue. 
Table 3. Construct and survey items

\begin{tabular}{|c|c|c|c|}
\hline & $\begin{array}{l}\text { Sub-dimensions } \\
\text { System Reliability (SRE) }(\alpha=0.87 ; \text { composite reliability: } 0.92 ; \text { AVE: }\end{array}$ & Mean & St. Dev. \\
\hline & 0.79) & & \\
\hline & The system operates reliably for the analytics. & 5.4 & 0.98 \\
\hline & The system performs reliably for the analytics. & & \\
\hline & The operation of the system is dependable for the analytics. & & \\
\hline & $\begin{array}{l}\text { System Adaptability (SAD) }(\alpha=0.85 \text {; composite reliability: 0.91; AVE: } \\
\text { 0.77) }\end{array}$ & & \\
\hline & The system can be adapted to meet a variety of analytics needs. & 5.6 & 1.10 \\
\hline & The system can flexibly adjust to new demands or conditions during analytics. & & \\
\hline & The system is flexible in addressing needs as they arise during the analytics. & & \\
\hline & System Integration (SIN) ( $\alpha=0.92 ;$ composite reliability: 0.94; AVE:0.86) & & \\
\hline & The system effectively integrates data from different areas of the company. & & \\
\hline $\begin{array}{l}\text { BDA System } \\
\text { Quality }\end{array}$ & $\begin{array}{l}\text { The system pulls together data that used to come from different places in the } \\
\text { company. }\end{array}$ & 5.5 & 1.12 \\
\hline $\begin{array}{l}\text { (Nelson et al., } \\
\text { 2005); }\end{array}$ & $\begin{array}{l}\text { The system effectively combines different types of data from all areas of the } \\
\text { company. }\end{array}$ & & \\
\hline $\begin{array}{l}\text { (Parasuraman } \\
\text { et al., 2005) }\end{array}$ & $\begin{array}{l}\text { System Accessibility (SAC) }(\alpha=0.88 \text {; composite reliability: } 0.93 \text {; } \\
\text { AVE:0.82 ) }\end{array}$ & & \\
\hline & The system allows information to be readily accessible to me. & 5.5 & 1.01 \\
\hline & The system makes information very accessible. & & \\
\hline & The system makes information easy to access. & & \\
\hline & $\begin{array}{l}\text { System Response Time (SRT) ( } \alpha=0.88 \text {; composite reliability: 0.92; } \\
\text { AVE:0.81) }\end{array}$ & & \\
\hline & The system does not take long time to process my requests. & 5.5 & 1.06 \\
\hline & The system provides information in a timely fashion. & & \\
\hline & The system processes my requests quickly. & & \\
\hline & System Privacy (SPR) ( $\alpha=0.93 ;$ composite reliability:0.95; AVE:0.88) & & \\
\hline & The system protects information about personal issues. & & \\
\hline & This system protects information about personal identity. & 5.7 & 1.21 \\
\hline & $\begin{array}{l}\text { The system offers a meaningful guarantee that it will not share private } \\
\text { information. }\end{array}$ & & \\
\hline & Sub-dimensions & Mean & St.Dev. \\
\hline & Completeness (ICO) $(\alpha=0.87$; composite reliability: 0.92; AVE: 0.80) & & \\
\hline & $\begin{array}{l}\text { The business analytics used: } \\
\text { provides a complete set of information. }\end{array}$ & 5.30 & 1.16 \\
\hline & produces comprehensive information. & & \\
\hline & provides all the information needed. & & \\
\hline $\begin{array}{l}\text { Inrormation } \\
\text { Ouality }\end{array}$ & Currency (ICR)) ( $\alpha=0.86$; composite reliability:0.92 ; AVE:0.79) & & \\
\hline (Nelson et al., & provides the most recent information. & 548 & 106 \\
\hline & produces the most current information. & & \\
\hline & always provides up-to-date information. & & \\
\hline & Format (IFO) ( $\alpha=0.88 ;$ composite reliability: 0.93; AVE:0.80) & & \\
\hline & The information provided by the analytics is & & \\
\hline & The information provided by the analytics is __ well laid out. & 5.41 & 1.10 \\
\hline & $\begin{array}{l}\text { The information provided by the analytics is __ clearly presented on the } \\
\text { screen. }\end{array}$ & & \\
\hline
\end{tabular}




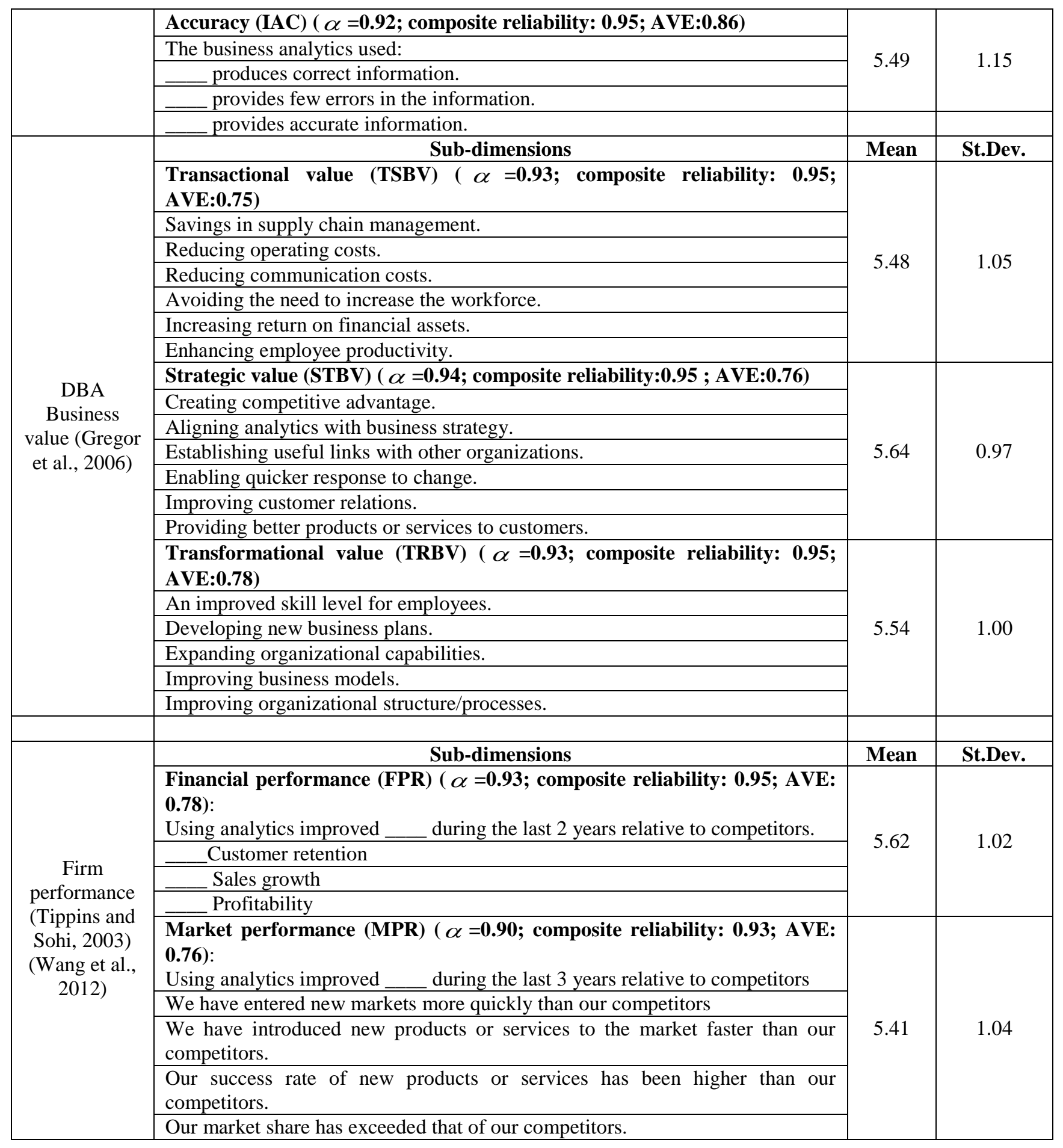


Table 4. Standardized loadings of the latent constructs in the model $(* * * p<0.001)$

\begin{tabular}{|c|c|c|}
\hline Latent Construct & Indicator & $\begin{array}{c}\text { Standard } \\
\text { loading }\end{array}$ \\
\hline \multirow{5}{*}{$\begin{array}{l}\text { Financial } \\
\text { Performance }\end{array}$} & FPR_1 & $0.83^{* * * *}$ \\
\hline & FPR_2 & $0.87^{* * *}$ \\
\hline & FPR_3 & $0.90^{* * * *}$ \\
\hline & FPR 4 & $0.90^{* * * *}$ \\
\hline & FPR_5 & $0.89^{* * *}$ \\
\hline \multirow{4}{*}{$\begin{array}{c}\text { Market } \\
\text { Performance }\end{array}$} & MPR_1 & $0.88^{* * *}$ \\
\hline & MPR_2 & $0.89^{* * * *}$ \\
\hline & MPR_3 & $0.92^{* * *}$ \\
\hline & MPR_4 & $0.80^{* * *}$ \\
\hline \multirow{3}{*}{$\begin{array}{c}\text { System } \\
\text { Reliability }\end{array}$} & SRE_1 & $0.88^{* * *}$ \\
\hline & SRE_2 & $0.91^{* * * *}$ \\
\hline & SRE_3 & $0.90^{* * *}$ \\
\hline \multirow{3}{*}{$\begin{array}{c}\text { System } \\
\text { Adaptability }\end{array}$} & SAD_1 & $0.89^{* * * *}$ \\
\hline & SAD_2 & $0.91^{* * *}$ \\
\hline & SAD_3 & $0.85^{* * *}$ \\
\hline \multirow{3}{*}{$\begin{array}{c}\text { System } \\
\text { Integration }\end{array}$} & SIN_1 & $0.91^{* * *}$ \\
\hline & SIN_2 & $0.95^{* * * *}$ \\
\hline & SIN_3 & $0.93^{* * *}$ \\
\hline \multirow{3}{*}{$\begin{array}{c}\text { System } \\
\text { Accessibility }\end{array}$} & SAC_1 & $0.90^{* * *}$ \\
\hline & SAC_2 & $0.91^{* * * *}$ \\
\hline & SAC_3 & $0.90^{* * * *}$ \\
\hline \multirow{3}{*}{$\begin{array}{c}\text { System Response } \\
\text { Time }\end{array}$} & SRT_1 & $0.88^{* * * *}$ \\
\hline & SRT 2 & $0.92^{* * *}$ \\
\hline & SRT_3 & $0.91^{* * *}$ \\
\hline \multirow{3}{*}{ System Privacy } & SPR_1 & $0.95^{* * * *}$ \\
\hline & SPR_2 & $0.91^{* * *}$ \\
\hline & SPR_3 & $0.94^{* * *}$ \\
\hline \multirow{3}{*}{ Completeness } & ICO_1 & $0.90^{* * * *}$ \\
\hline & ICO_2 & $0.92^{* * *}$ \\
\hline & ICO_3 & $0.87^{* * * *}$ \\
\hline \multirow{3}{*}{ Currency } & ICR_1 & $0.91^{\text {**** }}$ \\
\hline & ICR_2 & $0.85^{* * *}$ \\
\hline & ICR_3 3 & $0.90^{* * * *}$ \\
\hline \multirow{3}{*}{ Format } & IFR_1 & $0.87^{* * * *}$ \\
\hline & IFR_2 & $0.92^{* * *}$ \\
\hline & IFR 33 & $0.90^{* * * *}$ \\
\hline \multirow{3}{*}{ Accuracy } & IAC_1 & $0.93^{* * * *}$ \\
\hline & IAC _2 & $0.93^{* * * *}$ \\
\hline & IAC_3 & $0.93^{* * *}$ \\
\hline \multirow{6}{*}{$\begin{array}{c}\text { Transactional } \\
\text { Business Value }\end{array}$} & TSBV_1 & $0.89^{* * * *}$ \\
\hline & TSBV_2 & $0.89^{* * *}$ \\
\hline & TSBV_3 & $0.86^{* * * *}$ \\
\hline & TSBV_4 & $0.83^{* * *}$ \\
\hline & TSBV_5 5 & $0.86^{* * * *}$ \\
\hline & TSBV 6 & $0.85^{* * *}$ \\
\hline \multirow{6}{*}{$\begin{array}{c}\text { Strategic } \\
\text { Business Value }\end{array}$} & STBV_1 & $0.87^{* * * *}$ \\
\hline & STBV_2 & $0.86^{* * *}$ \\
\hline & STBV_3 & $0.87^{* * *}$ \\
\hline & STBV_4 & $0.87^{* * * *}$ \\
\hline & STBV_5 & $0.86^{* * *}$ \\
\hline & STBV_6 & $0.89^{* * *}$ \\
\hline \multirow{5}{*}{$\begin{array}{c}\text { Transformational } \\
\text { Business Value }\end{array}$} & TFBV_1 & $0.86^{* * * *}$ \\
\hline & TFBV_2 & $0.88^{* * *}$ \\
\hline & TFBV_3 & $0.90^{* * * *}$ \\
\hline & TFBV_4 & $0.88^{* * *}$ \\
\hline & TFBV_5 & $0.89^{* * *}$ \\
\hline
\end{tabular}


Table 5. Correlations of the first-order constructs

\begin{tabular}{|l|c|c|c|c|}
\hline \multicolumn{1}{|c|}{ Constructs } & $\mathbf{( 1 )}$ & $\mathbf{( 2 )}$ & $\mathbf{( 3 )}$ & (4) \\
\hline (1) BDA Information Quality & $\mathbf{0 . 9 0}$ & & & \\
\hline (2) BDA System Quality & 0.54 & $\mathbf{0 . 8 8}$ & & \\
\hline (3) BDA Business Value & 0.49 & 0.54 & $\mathbf{0 . 9 2}$ & \\
\hline (4) Firm Performance & 0.48 & 0.55 & 0.51 & $\mathbf{0 . 9 4}$ \\
\hline
\end{tabular}

Note: The bold numbers on the diagonal are the square root of the variance shared between the constructs and their measures. Off-diagonal elements are correlations among constructs. For discriminant validity, diagonal elements should be larger than off-diagonal elements.

\subsection{Structural Model}

The results in the Figure 2 indicate that system quality and business value enhanced firm performance with the path coefficients of $0.49(\mathrm{p}<0.001)$ and $0.30(\mathrm{p}<0.05)$ respectively, explaining $76 \%$ of its variance. Information quality insignificantly enhanced firm performance with the path coefficients of 0.15 (not supported). Both system and information quality enhanced business value with the path coefficients of $0.61(\mathrm{p}<0.001)$ and $0.29(\mathrm{p}<0.01)$ respectively, explaining $74 \%$ of its variance. Besides, system quality enhanced information quality with the path coefficient of $0.84(\mathrm{p}<0.001)$, explaining $70.0 \%$ of its variance. In sum, the $\mathrm{R}^{2}$ scores of dependent variables were $70 \%$ for information quality, $74 \%$ for business value and $76 \%$ for firm performance. Thus the study found support for all the hypotheses except H5.

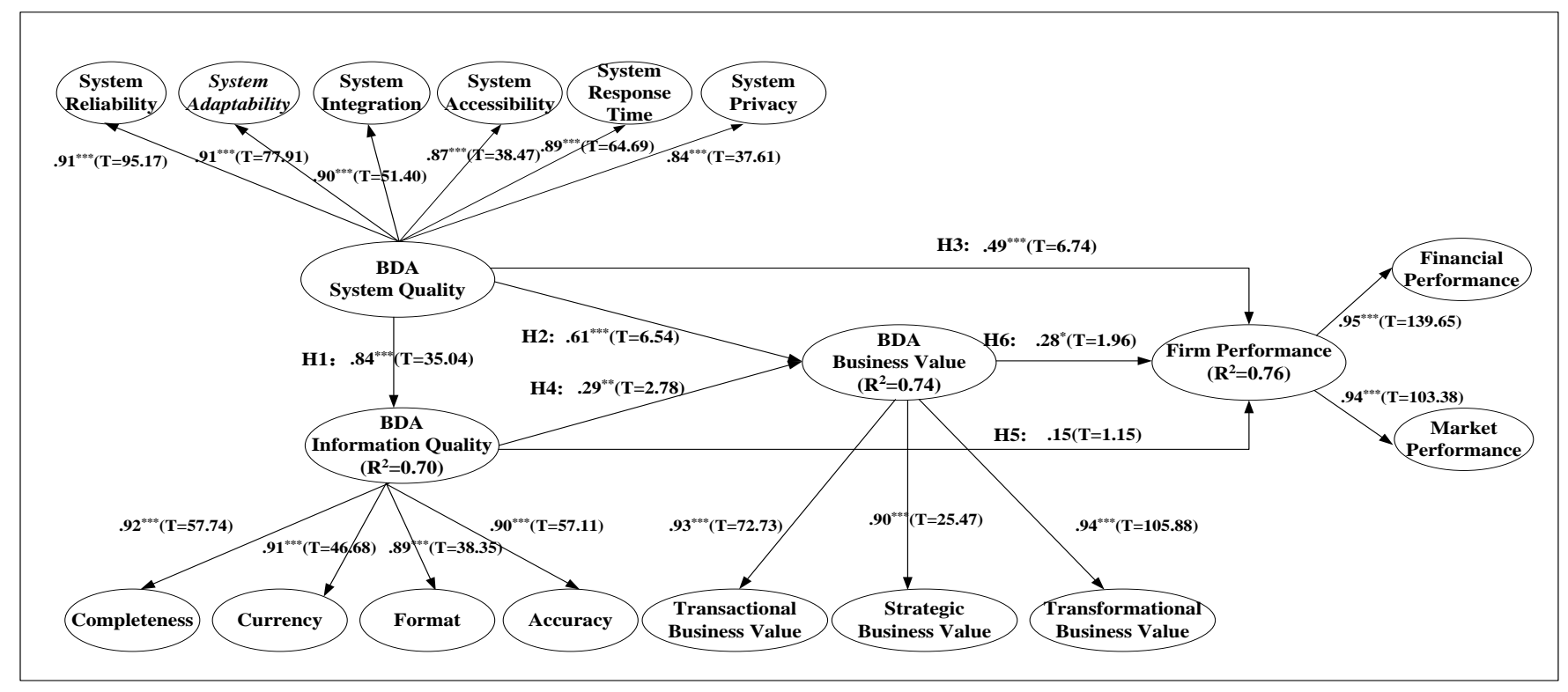

Figure 2: Full structural model

Note: $* * * p<0.001, * * p<0.01, * p<0.05$ 


\subsection{Mediation Test}

A review of the big data literature reveals that the quality of technology and information directly influences business value in data economy (Wixom et al., 2013). The importance of the relationship between analytics quality, business value and firm performance was evidenced in a study over 30 industries across 100 countries (Lavalle et al., 2011). Indeed, the sustainability of big data programs in an organization is determined by the extent of business value (Mithas et al., 2013,p.18). Despite the importance of analytics quality in generating business value and enhancing firm performance, there is a paucity of empirical studies which confirm this relationship in a big data environment (Goes, 2014; Lavalle et al., 2011; Wixom et al., 2013). Thus we propose that business value may mediate the impact of BDA system quality and information quality on the firm performance, and also BDA information quality may mediate the relationship between BDA system quality and BDA business value. The procedure for mediation analysis is based on the path coefficients and standard errors of the direct paths between (i) independent and mediating variables (i.e., iv $\rightarrow \mathrm{m}$ ) and (ii) mediating and dependent variables (i.e., $\mathrm{m} \rightarrow \mathrm{dv}$ ). The results of the PLS analysis are used to calculate the extent to which a construct mediates the relationship between the independent variable and the dependent variable(Baron and Kenny, 1986). For example, the size of the mediating effect between BDA system quality (iv) and firm performance (dv) mediated by BDA business value (m) is the product of the standardized paths between iv and $\mathrm{m}$ and between $\mathrm{m}$ and $\mathrm{dv}$ (Akter et al., 2011). The standard deviation of the mediated path can be computed based on the magnitudes and the variance of the paths among iv, $\mathrm{m}$, and $\mathrm{dv}$. The results of the analyses of paths in the model are in Table 6.

Table 6. Mediation Test Result

\begin{tabular}{|c|c|c|}
\hline Mediated Path & Z Statistic & VAF \\
\hline $\mathrm{BDA} \mathrm{SQ} \rightarrow \mathrm{BDA} \mathrm{BV} \rightarrow \mathrm{FPER}$ & $2.04 *$ & $31 \%$ \\
\hline $\mathrm{BDA}$ IQ $\rightarrow$ BDA BV $\rightarrow$ FPER & $1.72^{*}$ & $37 \%$ \\
\hline $\mathrm{BDA} \mathrm{SQ} \rightarrow \mathrm{BDA} \mathrm{IQ} \rightarrow \mathrm{BDA} \mathrm{BV}$ & $2.88 * *$ & $29 \%$ \\
\hline
\end{tabular}


The findings show a significant mediating impact of BDA business value between system quality and firm performance and BDA information quality and firm performance (Sobel, 1982). The findings also show that BDA information quality significantly mediates the relationship between BDA SQ and BDA BV. The study also estimates the magnitude of the indirect effect by calculating VAF (Variance Accounted For) value, which represents the ratio of the indirect effect to the total effect (Hair Jr et al., 2013). The results indicate that BDA BV explains about $31 \%$ of the total effect of BDA SQ on FPER and 37\% effect of BDA IQ on FPER. Similarly, BDA IQ explains about 29\% of the total effect of BDA SQ on FPER (Iacobucci, 2008). Therefore, both BDA BV and BDA IQ have been proven as significant mediators in estimating the effects of BDA SQ on firm performance.

\section{DISCUSSIONS}

\subsection{Summary of Findings}

The primary objective of this study was to examine the effects of system quality and information quality on business value and firm performance. The results show that system quality explains $70 \%$ of variance of information quality, $74 \%$ of variance of business value and $76 \%$ of variance of firm performance. It is clearly evident that system quality had a stronger influence on business value compared to information quality. Besides, system quality enhanced information quality with the path coefficient of 0.84 , which in turn influenced business value and firm performance.

The present study provided a good perspective to explore the mechanisms of system quality and information quality to firm performance via business value in big data environment. Specifically, business value mediates the effect between system quality and firm performance. This result implies that big data firms can improve system quality and information quality constantly to improve business value, and then enhance firm performance. 


\subsection{Implications for Research}

Firms spend millions of dollars on business analytics to enhance business value and firm performance. However, studies on business analytics to business outcomes show mixed results. Therefore a theory explaining how BDA can improve performance is a critical challenge to big data research. Our conceptual framework, combining rich theoretical approach of RBT and IS success, extends theory in the stream of BDA research. The findings clearly inform the debate on how to leverage BDA better than others. Specifically, drawing on the RBT and IS success, our approach is among the first in assessing the link between quality dynamics, business value and firm performance in BDA research and practices. The findings are consistent with the extant big data literature, which identifies the importance of technology and information quality on critical organizational outcomes as success factors of big data analytics projects (Kiron et al., 2014; Wamba et al., 2015; Wixom et al., 2013).

Synthesizing the RBT and IS success theories, the study develops and validates a quality dominant logic in big data research with two dimensions (i.e., system quality, information quality) and ten subdimensions (i.e., system reliability, system adaptability, system integration, system accessibility, system privacy, system response time, completeness, currency, format and accuracy). By encompassing the combined explanatory power of each quality construct, our model advances quality logic in big data research while presenting a parsimonious research model. The study extends relevant theories in BDA by framing two dimensions and ten sub-dimensions of analytics quality on two outcome constructs (i.e., BVAL and FPER), which have not been investigated before. The study adds further rigor by defining each construct and developing its measurement scale against the backdrop of BDA research.

Big data usually includes data sets with sizes beyond the ability of commonly used software tools to capture, curate, manage, and process data within a tolerable elapsed time (Snijders et al. 2012). Big data requires new forms of integration to uncover large hidden values from large datasets that are 
diverse, complex, and of a massive scale (Ibrahim et al. 2015). Thus, the present study extends IS success research by highlighting the importance of quality dynamics (i.e., system quality and information quality) in big data, which will be vital to the data management, diagnosis and value generating process. From RBT perspective, this focus on system characteristics and information quality perspectives stresses the importance of solid insights in data economy to generate business value and enhance firm performance.

\subsection{Implications for Practice}

The proposed quality model provides managers with a tool for conducting an integrated analysis and design of BDA systems. The findings make it evident that a good technological platform (e.g., system quality) is not enough to deliver the desired levels of business value and improve firm performance, it is also important to ensure robust information quality. Thus, managers need to focus on both the quality of BDA system and information. These findings could be used as a useful roadmap for identifying and solving particular quality issue at different levels of system and information. The findings highlight that quality issues arising in the dimensions of BDA have different natures, such as, 'technology' (i.e., system), and 'information' (i.e., solid insights) quality derived from BDA. Overall the findings of the study provide big data managers an understanding of how an individual quality dimension contribute to the formation of business value and firm performance. The findings also illuminate the roles of system and information quality as decisionmaking variables in predicting business value and firm performance. Firm performance is the ultimate outcome variable, which is identified as one of the critical challenges to identify and replicate the best BDA practices around the world. Therefore, the findings on firm performance and its antecedents (i.e., business value, system and information quality) will facilitate the scalability of BDA. The findings of the study also confirm the mediating role of business value in predicting firm performance with system quality as an antecedent. These findings suggest that managers should 
consider quality dynamics and business value as important strategic objectives to ensure improved firm performance.

\subsection{Limitations and Future Research}

This study has some limitations that open up interesting opportunities for future research. First, this study is carried out with a cross-sectional research design, in which all measurement items were collected at the same point of time. A longitudinal study can extend the current research by capturing the dynamics of the technology use phenomenon. Second, this research employs only one method for data collection. Objective data from multiple sources can be used for further verifying the proposed research model. Future research can also monitor the actual number of features used, and then examine the relationships between proposed models about actual use of the system and also work performance. Third, from the results, we can know that information quality insignificantly influences firm performance, indicating that perhaps there might be other variables (i.e., analytics capability or analytics-strategy alignment) affecting this relationship. Therefore, future research can explore the deep relationship between quality dynamics, business value and firm performance.

\subsection{Conclusions}

Analytics and productivity are intricately interrelated. Although it is challenging for all organizations to invest in analytics skills, technology and embrace the culture, successful organizations continue gaining competitive advantages by linking analytics with firm performance. Analytics is a holistic process combining system and information to gain business value and foster growth. The process needs to be designed as an ecosystem to generate new insights for business by sharing information and facilitating decision making. This is an exciting time for analytics research and to extend qualityvalue-performance relationship in big data environment. The findings of the study provide an important step to facilitate theoretical and practical thinking in big data and address future research questions at the intersection of production, technology, business and society. 


\section{References}

Agarwal, R., Dhar, V., 2014. Editorial-Big Data, Data Science, and Analytics: The Opportunity and Challenge for IS Research. Information Systems Research 25, 443-448.

Akter, S., D'Ambra, J., Ray, P., 2011. Trustworthiness in mHealth information services: an assessment of a hierarchical model with mediating and moderating effects using partial least squares (PLS). Journal of the American Society for Information Science and Technology 62, 100-116.

Akter, S., D'Ambra, J., Ray, P., 2010. Service quality of mHealth platforms: development and validation of a hierarchical model using PLS. Electronic Markets 20, 209-227.

Amit, R., Schoemaker, P.J., 1993. Strategic assets and organizational rent. Strategic management journal 14, 33-46.

Anand, A., Fosso Wamba, S., Sharma, S., 2013. The Effects of Firm IT Capabilities on Firm Performance: The Mediating Effects of Process Improvement 24th Australasian Conference on Information Systems, Melbourne, Australia.

APICS, 2012. APICS 2012 Big Data Insights and Innovations Executive Summary.

Bagozzi, R.P., Yi, Y., Phillips, L.W., 1991. Assessing construct validity in organizational research. Administrative Science Quarterly 36, 421-458.

Barney, J., 1991. Firm resources and sustained competitive advantage. Journal of management 17, 99-120.

Barney, J., Wright, M., Ketchen, D.J., 2001. The resource-based view of the firm: Ten years after 1991. Journal of management 27, 625-641.

Barney, J.B., 2014. How marketing scholars might help address issues in resource-based theory. Journal of the Academy of Marketing Science 42, 24-26.

Barney, J.B., Clark, D.N., 2007. Resource-based theory: Creating and sustaining competitive advantage. Oxford University Press Oxford.

Barney, J.B., Hesterly, W.S., 2012. Strategic management and competitive advantage: concepts and cases. Pearson/Prentice Hall Upper Saddle River, NJ.

Baron, R.M., Kenny, D.A., 1986. The moderator-mediator variable distinction in social psychological research: conceptual, strategic and statistical considerations. Journal of personality and social psychology 51 , 1173-1182.

Barton, D., Court, D., 2012a. Making advanced analytics work for you. Harvard business review 90, 78.

Barton, D., Court, D., 2012b. Making advanced analytics work for you. Harvard Business Review 90, 79-83.

Barua, A., Konana, P., Whinston, A.B., Yin, F., 2004. An Empirical Investigation of Net-Enabled Business Value. MIS Quarterly 28, 585-620.

Barua, A., Kriebel, C., Mukhopadhyay, T., 1995a. Information technology and business value: an analytic and empirical investigation. INFORMATION SYSTEMS RESEARCH 6, 3-23.

Barua, A., Kriebel, C.H., Mukhopadhyay, T., 1995b. Information Technology and Business Value: An Analytic and Empirical Investigation. Information Systems Research 6, 3-23.

Bharadwaj, A., 2000. A resource-based perspective on information capability and firm performance: an empirical investigation. MIS Quarterly 24, 169-196.

Bhatt, G.D., Grover, V., 2005. Types of Information Technology Capabilities and Their Role in Competitive Advantage: An Empirical Study. Journal of Management Information Systems 22, 253-277.

Brynjolfsson, E., Hitt, L.M., 2000. Beyond Computation: Information Technology, Organizational Transformation and Business Performance. The Journal of Economic Perspectives 14, 23-48.

Brynjolfsson, E., Yang, S., 1996. Information technology and productivity: a review of the literature. Advances in computers 43, 179-214.

Chang, J.C.-J., King, W.R., 2005. Measuring the Performance of Information Systems: A Functional Scorecard. Journal of Management Information Systems 22, 85-115.

Chin, W.W., 2001. PLS-graph user's guide. CT Bauer College of Business, University of Houston, USA.

Chin, W.W., 2010. How to write up and report PLS analyses. Handbook of partial least squares, 655-690.

Columbus, L., 2014a. 84\% Of Enterprises See Big Data Analytics Changing Their Industries' Competitive Landscapes In The Next Year, Forbes.

Columbus, L., 2014b. Making Analytics Accountable: 56\% Of Executives Expect Analytics to Contribute To $10 \%$ Or More Growth in 2014, Forbes.

Court, D., 2015. Getting big impact from big data, McKinsey Quarterly, pp. 1-8. 
D'Ambra, J., Wilson, C.S., Akter, S., 2013. Application of the task-technology fit model to structure and evaluate the adoption of E-books by Academics. Journal of the American Society for Information Science and Technology 64, 48-64.

Davenport, T.H., 2006. Competing on Analytics. Harvard Business Review 84, 98-107.

Davenport, T.H., Barth, P., Bean, R., 2012a. How 'Big Data' is Different. MIT Sloan Management Review 54, 43-46.

Davenport, T.H., Barth, P., Bean, R., 2012b. How Big Data Is Different. MIT Sloan Management Review 54, 43-46.

Davenport, T.H., Harris, J.G., 2007. Competing on analytics: the new science of winning. Harvard Business School Press.

DeLone, W.H., McLean, E.R., 1992. Information systems success: the quest for the dependent variable. Information Systems Research 3, 60-95.

DeLone, W.H., McLean, E.R., 2003. The DeLone and McLean Model of Information Systems Success: A Ten-Year Update. Journal of Management Information Systems 19, 9-30.

DeLone, W.H., McLean, E.R., 2004. Measuring e-Commerce Success: Applying the DeLone \& McLean Information Systems Success Model. International Journal of Electronic Commerce 9, 31-47.

Devaraj, S., Kohli, R., 2003. Performance impacts of information technology: Is actual usage the missing link? Management science 49, 273-289.

Edwards, J.R., 2001. Multidimensional constructs in organizational behavior research: An integrative analytical framework. Organizational Research Methods 4, 144-192.

Efron, B., Tibshirani, R., 1993. An introduction to the bootstrap. Chapman \& Hall/CRC.

Fornell, C., Larcker, D.F., 1981a. Evaluating structural equation models with observable variables and measurement error. Journal of Marketing Research 18, 39-50.

Fornell, C., Larcker, D.F., 1981b. Structural equation models with unobservable variables and measurement error: Algebra and statistics, 382-388. Journal of marketing research 18, 382-388.

Fosso Wamba, S., Akter, S., Edwards, A., Chopin, G., Gnanzou, D., 2015. How 'big data' can make big impact: Findings from a systematic review and a longitudinal case study. International Journal of Production Economics 165, 234-246.

Goes, P.B., 2014. Big Data and IS Research. MIS Quarterly 38, iii-viii.

Gorla, N., Somers, T.M., Wong, B., 2010. Organizational impact of system quality, information quality, and service quality. The Journal of Strategic Information Systems 19, 207-228.

Grant, R.M., 1991. The Resource-based Theory of Competitive Advantage: Implications for Strategy Formulation. California Management Review, University of California.

Grant, R.M., 2002. The resource-based theory of competitive advantage. Strategy: Critical Perspectives on Business and Management 135.

Gregor, S., Martin, M., Fernandez, W., Stern, S., Vitale, M., 2006. The transformational dimension in the realization of business value from information technology. The Journal of Strategic Information Systems 15, 249-270.

Hair, J.F., Hult, G.T.M., Ringle, C., Sarstedt, M., 2013. A primer on partial least squares structural equation modeling (PLS-SEM). SAGE Publications, Incorporated.

Hair, J.F., Ringle, C.M., Sarstedt, M., 2011. PLS-SEM: Indeed a silver bullet. The Journal of Marketing Theory and Practice 19, 139-152.

Hair Jr, J.F., Hult, G.T.M., Ringle, C., Sarstedt, M., 2013. A primer on partial least squares structural equation modeling (PLS-SEM). Sage Publications.

Hulland, J., Ryan, M.J., Rayner, R.K., 2010. Modeling customer satisfaction: a comparative performance evaluation of covariance structure analysis versus partial least squares, Handbook of partial least squares. Springer, pp. 307-325.

Iacobucci, D., 2008. Mediation analysis. Sage.

Jayachandran, S., Sharma, S., Kaufman, P., Raman, P., 2005. The Role of Relational Information Processes and Technology Use in Customer Relationship Management. Journal of Marketing 69, 177-192.

Kaufman, B.E., 2015. The RBV theory foundation of strategic HRM: critical flaws, problems for research and practice, and an alternative economics paradigm. Human Resource Management Journal, n/a-n/a.

Kiron, D., Prentice, P.K., Ferguson, R.B., 2014. The analytics mandate. MIT Sloan management review 55, 1 25 . 
Kozlenkova, I.V., Samaha, S.A., Palmatier, R.W., 2014. Resource-based theory in marketing. Academy of Marketing Science. Journal 42, 1-21.

Lavalle, S., Lesser, E., Shockley, R., Hopkins, M.S., Kruschwitz, N., 2011. Big Data, Analytics and the Path From Insights to Value. Mit Sloan Management Review 52, 21-32.

McAfee, A., Brynjolfsson, E., 2012a. Big data: the management revolution. Harvard business review 1.

McAfee, A., Brynjolfsson, E., 2012b. Big data: the management revolution. Harvard business review, 60-66, 68, 128.

McAfee, A., Brynjolfsson, E., 2012c. Big Data: The Management Revolution. Harvard Business Review 90, 60-68.

Melville, N., Kraemer, K., Gurbaxani, V., 2004. INFORMATION TECHNOLOGY AND ORGANIZATIONAL PERFORMANCE: AN INTEGRATIVE MODEL OF IT BUSINESS VALUE. MIS Quarterly 28, 283-322.

Mithas, S., Lee, M.R., Earley, S., Murugesan, S., Djavanshir, R., 2013. Leveraging Big Data and Business Analytics. IT Professional 15, 18-20.

Mithas, S., Ramasubbu, N., Sambamurthy, V., 2011. How information management capability influences firm performance. MIS Quarterly 35, 237-256.

Mooney, J.G., Gurbaxani, V., Kraemer, K.L., 1996. A process oriented framework for assessing the business value of information technology. SIGMIS Database 27, 68-81.

Morgan, N.A., Slotegraaf, R.J., Vorhies, D.W., 2009. Linking marketing capabilities with profit growth. International Journal of Research in Marketing 26, 284-293.

Nelson, R.R., Todd, P.A., Wixom, B.H., 2005. Antecedents of information and system quality: an empirical examination within the context of data warehousing. Journal of Management Information Systems 21, 199. 235.

Nunnally, J.C., Bernstein, I.H., 1994. Psychometric Theory (Third Edition). McGraw-Hill, New York.

Parasuraman, A., Zeithaml, V., Berry, L., 2005. ES-QUAL a multiple-item scale for assessing electronic service quality. Journal of Service Research 7, 213-233.

Peteraf, M.A., Barney, J.B., 2003. Unraveling the resource-based tangle. Managerial and decision economics 24, 309-323.

Podsakoff, P.M., Organ, D.W., 1986. Self-Reports in Organizational Research: Problems and Prospects. Journal of Management 12, 531-544.

Ram, J., Corkindale, D., Wu, M.-L., 2014. ERP adoption and the value creation: Examining the contributions of antecedents. Journal of Engineering and Technology Management 33, 113-133.

Ray, G., Muhanna, W.A., Barney, J.B., 2005. Information technology and the performance of the customer service process: A resource-based analysis. MIS quarterly, 625-652.

Roach, S.S., Stanley, M., Co, 1987. America's Technology Dilemma: A Profile of the Information Economy. Morgan Stanley.

Santhanam, R., Hartono, E., 2003. Issues in Linking Information Technology Capability to Firm Performance. MIS Quarterly 27, 125-153.

Schläfke, M., Silvi, R., Möller, K., 2013. A framework for business analytics in performance management. International Journal of Productivity and Performance Management 62, 110-122.

Segers, A.H., 1997. Assessing the unidimensionality of measurement: A paradigm and illustration within the context of information systems. Omega 25, 107-121.

Sobel, M.E., 1982. Asymptotic confidence intervals for indirect effects in structural equation models. Sociological methodology 13, 290-312.

Solow, R., 1987. We'd better watch out. New York Times Book Review.

Srinivasan, U., Arunasalam, B., 2013. Leveraging Big Data Analytics to Reduce Healthcare Costs.

Strassmann, P.A., 1990. The Business Value of Computers: An Executive's Guide. Information Economics Press.

Teo, T.S.H., Wong, P.K., 1998. An empirical study of the performance impact of computerization in the retail industry. Omega 26, 611-621.

Tippins, M.J., Sohi, R.S., 2003. IT competency and firm performance: is organizational learning a missing link? Strategic Management Journal 24, 745-761.

Trkman, P., Bronzo Ladeira, M., De Oliveira, M., McCormack, K., 2012. Business Analytics, Process Maturity and Supply Chain Performance, in: Daniel, F., Barkaoui, K., Dustdar, S. (Eds.), Business Process Management Workshops. Springer Berlin Heidelberg, pp. 111-122. 
Verbraken, T., Lessmann, S., Baesens B., 2012. Toward Profit-Driven Churn Modeling with Predictive Marketing Analytics, Proceedings of the 11th Workshop on e-Business (WEB'2012), Orlando, FL, USA.

Wamba, S.F., Akter, S., Edwards, A., Chopin, G., Gnanzou, D., 2015. How 'big data'can make big impact: Findings from a systematic review and a longitudinal case study. International Journal of Production Economics.

Wang, N., Liang, H., Zhong, W., Xue, Y., Xiao, J., 2012. Resource Structuring or Capability Building? An Empirical Study of the Business Value of Information Technology. J. Manage. Inf. Syst. 29, 325-367.

Wetzels, M., Odekerken-Schroder, G., Van Oppen, C., 2009. Using PLS path modeling for assessing hierarchical construct models: guidelines and empirical illustration. MIS Quarterly 33, 177.

Wixom, B.H., Todd, P.A., 2005. A theoretical integration of user satisfaction and technology acceptance. Information Systems Research 16, 85-102.

Wixom, B.H., Yen, B., Relich, M., 2013. Maximizing value from business analytics. MIS Quarterly Executive 12, 111-123.

Zuboff, S., 1988. In the age ofthe smart machine. Basic Book, NY. 